\title{
Factors associated with the institutionalization of the elderly: a case-control study
}

Ezequiel Vitório Lini' Marilene Rodrigues Portella ${ }^{\top}$ Marlene Doring'

\section{Abstract}

Objective: to identify the factors associated with the institutionalization of the elderly. Method: a case-control, population-based study was performed with 387 elderly people. The study considered cases of elderly people $(n=191)$ living in long-term care facilities, and a control group ( $\mathrm{n}=196)$ who lived in homes in urban areas of the city. Both groups were identified from the records of the Family Health Strategy and were randomly selected. Institutionalization was considered a dependent variable, and sociodemographics, clinical factors, functional status, and cognitive impairment were considered independent variables. Comparison between groups was analyzed using the Chi-squared and Pearson tests and the logistic regression model was used in adjusted analysis, with measurements of effect expressed as odds ratio with a 95\% confidence interval. Variables with $p \leq 0.20$ were considered for entry in the multiple model. Results: variables that remained associated with institutionalization in multiple analysis were: not having a partner $(\mathrm{OR}=9.7)$, not having children $(\mathrm{OR}=4.0)$, presenting cognitive impairment $(\mathrm{OR}=11.4)$, and depending on others to perform basic activities of daily living $(\mathrm{OR}=10.9)$. Conclusion: cognitive impairment and dependency for basic activities of daily living were more strongly associated with institutionalization. Home care strategies and preventive actions for risk factors should be stimulated to delay the referral of elderly people to Long Term Care Facilities for the Elderly, and to develop strategies that allow the elderly to remain socially active.

Universidade de Passo Fundo (UPF), Programa de Pós-Graduação em Envelhecimento Humano. Passo Fundo, RS, Brasil.

Keywords: Elderly. Homes for the Aged. Risk Factors. Dementia. Activities of Daily Living. 


\section{INTRODUCTION}

The prolongation of life has become a reality in Brazil due to the reduction of mortality rates and infectious diseases and a significant evolution in health care. However, with a greater proportion of elderly people, the importance of conditions of dependency, which will at some point require greater care, increases ${ }^{1}$.

A number of complications, such as the presence of chronic diseases and limitations in activities of daily living, mean there is a need for professional monitoring of health, including referral to long-term care facilities for the elderly (LTCFE) ${ }^{2}$.

Today, LTCFE operate with practically all their beds occupied, and growth of between 100\% and $500 \%$ in the number of elderly people in need of non-family care can be expected in the next decade. Therefore, institutions will have to absorb much of this demand ${ }^{3}$. The need for care outside the home is due to the installation of chronic diseases and their complications and the unavailability of family members to provide the continuous support that elderly dependents need, either because of the difficulty of staying at home full time or due to the impossibility of hiring specialized professionals ${ }^{4}$.

A number of reasons for institutionalization have been reported. In a study by Perlini et al. ${ }^{5}$, the factors most cited by relatives when deciding to institutionalize an elderly person were the reduced number of family members, the absence of physical, financial and psychological conditions for the provision of home care and the desire of the elderly to not disturb their family members. Relationship problems with relatives, widowhood, multiple diseases and dementia syndrome were the reasons identified by Fonseca et al. ${ }^{6}$.

Understanding the factors that lead to institutionalization are fundamental if family members and health professionals are to be aware of prevention possibilities and can identify when institutionalization is truly required. The administrators, legislators and supervisory bodies of the LTCFE can, through greater knowledge of indicators of institutionalization, organize measures to better receive and manage this population. The present study therefore aimed to identify the main factors associated with the institutionalization of the elderly.

\section{METHOD}

A population-based case-control study with 387 elderly residents was carried out in a medium-sized municipality, located in the north of Rio Grande do Sul, $293 \mathrm{~km}$ from the state capital. The estimated population was 187,298 thousand inhabitants. Of these, 22,222 were elderly, being aged 60 years or over?

The case group was represented by 191 individuals aged $\geq 60$ years living in an LTCFE, and a control group made up of 196 individuals aged $\geq 60$ years living in urban households of the municipality. Institutionalized elderly people from other municipalities were excluded in order to maintain the same origins for cases and controls.

At the time of collection, the municipality had 16 LTCFE, which housed 363 elderly persons. Of these, 13 of those selected agreed to participate (288 elderly), of which three were philanthropic and ten were private. The sample calculation indicated that 186 elderly people would be needed for the case group, plus 10\% to compensate for possible losses (refusals and ineligibility), totaling 205 interviews. Individuals aged $\geq 60$ years were selected from each LTCFE based on the proportion that each facility represented of the total.

Controls were selected from the urban territorial division demarcated by the Coordenadoria de Proteção Social Básica (Basic Social Protection Coordination) of the municipality of Passo Fundo, Rio Grande do Sul. This body divides the municipality into four major sectors: Sector I: northeast region; Sector II: northwest region; Sector III: southeast region; Sector IV: southwest region. Based on these territorial divisions, a Unidade Básica de Saúde (Basic Health Unit) (UBS) was drawn from each of the sectors, from which the records (name and address) of all individuals aged $\geq 60$ years were obtained. From the list of these elderly persons, 52 subjects were drawn from each quadrant, to ensure one control for each case, giving a total of 208 elderly people.

The data was collected from April to August 2014 in households and the LTCFE by a trained team composed of six scholarship students and volunteers from the undergraduate nursing course of the University of Passo Fundo, Rio Grande do Sul. A structured questionnaire was applied under the continuous supervision of the researcher responsible. 
The elderly were interviewed individually, in specifically reserved locations, both in the LTCFE and in their homes. If it was the randomly selected elderly person was unable to respond, the information was obtained from the caregiver or guardian in the household and by the responsible staff member in the LTCF.

Elderly persons who were hospitalized on the day of the interview were excluded. The losses were individuals who were not found in the household after three attempts by the interviewers on alternate days and times.

The defined outcome was institutionalization. The following variables were investigated to identify the possible factors associated with institutionalization in an LTCFE: gender; age; skin color/ethnicity; marital status; schooling; monthly income; number of children; practice of physical activity and selfreported health status; use of medication; presence of cognitive impairment and disability for basic activities of daily living (BADV). We investigated the presence of chronic diseases, including dementias. Among the possible dementias, Alzheimer's and other unspecified dementias (cases in which dementia was diagnosed but not classified) were found in medical records.

In order to investigate the presence of cognitive impairment, the Mini mental State Exam (MMSE) was used with the following cutoff points: 13 points for illiterate elderly people, 18 points for those with low and medium schooling (up to eight years of schooling) and 26 points for elderly persons with high levels of schooling (above eight years of schooling) 8 . The Pfeffer functional activities questionnaire (PFAQ)9, a scale applied to the caregiver/responsible person when the elderly person is unable to respond, whether due to severe dementia, aphasia, deafness, etc., was also used. This consists of verifying the presence of cognitive impairment from the capacity of the individual to perform certain functions, for example: if they are able to heat water, make a cup of coffee and turn off the stove after use; if they are able to greet friends properly; or pay attention to and discuss a television or radio program, among other activities. There are 11 questions with a maximum score of 33 points and a higher score represents a greater degree of dependence, which suggests the presence of cognitive impairment. The answers must conform to the standard of: yes, is capable (0); never did but could do now (0); has difficulty but does by self (1); never did and would have difficulty doing now (1); requires assistance (2); dependent (3). Scores greater or equal to 6 suggest cognitive impairment10.

The Katz Index11 was used to evaluate the performance of BADL. This evaluates the functional capacity to perform some basic daily activities, such as bathing, dressing, going to the bathroom, transferring from bed to chair and viceversa, sphincter control and unassisted feeding. The elderly with a classification of A were considered independent, or in other words, independent for all activities, while those classified as B, C, D, E, F, G and Other, or in other words dependent for at least one activity, were considered dependent.

Pearson's Chi-squared and Fisher's exact tests were used to compare the groups. In the multivariate analysis, logistic regression was used, with measures of effect expressed in odds ratio (OR) and 95\% confidence intervals $(95 \% \mathrm{CI})$. Variables with $\mathrm{p} \leq 0.20$ were considered for entry into the model.

The research project was approved by the Research Ethics Committee of the Universidade de Passo Fundo, under opinion no 504.100/2014. The elderly individuals or their carers signed a Free and Informed Consent Form before the interviews were carried out.

\section{RESULTS}

A total of 387 people aged $\geq 60$ years old were divided into 191 (49.4\%) elderly people living in LTCFE and 196 (50.6\%) elderly persons living in areas covered by the BHU. The majority were between 70 and 79 years old (34.6\%). The mean age was 75.1 years $( \pm 9.9)$, and $64.6 \%$ were female, $81.1 \%$ were white/Caucasian and $69.6 \%$ lived without partners (Table 1). In $27.9 \%$ of the interviews, help from third parties was necessary to complete the questionnaire.

Distribution by gender was similar between the institutionalized and non-institutionalized groups. In terms of income, the proportion of those earning above three minimum wages was four times greater in the institutionalized group $(\mathrm{p}=0.003)$. The percentage of elderly persons who did not attend 
school was higher in the institutionalized group ( $\mathrm{p}$ $<0.001)$ (Table 1)

A total of $90.5 \%$ of the institutionalized elderly and $49.5 \%$ of the elderly who lived in their homes had no partner $(\mathrm{p}<0.001)$. When analyzing age group, $49.2 \%$ of the institutionalized elderly persons were over 80 years old, compared to $16.8 \%(\mathrm{p}<0.001)$ of the elderly who lived at home. Of the institutionalized elderly, 37.7\% had no children, compared with $9.2 \%$ of the elderly who lived in households $(p<0.001)$ (Table 1).

The practice of physical activity was significantly lower among the institutionalized elderly (30.4\%). In the institutionalized group, 50.3\% needed support when walking or did not walk, while among those who lived at home the proportion was $12.2 \%(\mathrm{p}<0.001)$ (Table 2). Among the difficulties or disabilities for walking, those who used wheelchairs or were bedridden $(65.7 \%)$ prevailed in the institutionalized group $(\mathrm{p}=0.003)$.

In the search for chronic diseases and disabilities, the institutionalized elderly persons had higher and more significant percentages of Alzheimer's (26.3\%), Parkinson's (9.5\%), other unspecified dementias $(13.7 \%)$ and stroke motor sequelae (13.7\%). Of those who lived at home, hypertension (69.9\%), heart disease $(27.0 \%)$ and cancers $(10.7 \%)$ were the most common (Table 2).

There were symptoms suggestive of dementia (using the MMSE and PFAQ tests) in $81.2 \%$ of the institutionalized elderly and $12.8 \%$ of those resident in households $(\mathrm{p}<0.001)$. At least one basic activity of daily living was dependent $(75.9 \%$ among the institutionalized and 9.7\% among the elderly living in households) $(\mathrm{p}<0.001)$ (Table 2$)$.

Table 1. Distribution of institutionalized elderly persons (cases) and elderly persons resident in households (controls) for sociodemographic variables (N=387). Passo Fundo, Rio Grande do Sul, 2014.

\begin{tabular}{|c|c|c|c|c|}
\hline Variables & $\begin{array}{l}\text { Cases } \\
\mathrm{n}(\%)\end{array}$ & $\begin{array}{l}\text { Controls } \\
\mathrm{n}(\%)\end{array}$ & $\begin{array}{l}\text { Total } \\
\mathrm{n}(\%)\end{array}$ & $p$ \\
\hline \multicolumn{5}{|l|}{ Gender } \\
\hline Male & $59(30.9)$ & $78(39.8)$ & $137(35.4)$ & 0,067 \\
\hline Female & $132(69.1)$ & $118(60.2)$ & $250(64.6)$ & \\
\hline \multicolumn{5}{|c|}{ Age group (in years) } \\
\hline 60 to 69 & $35(18.3)$ & $91(46.4)$ & $126(32.6)$ & $<0,001$ \\
\hline 70 to 79 & $62(32.4)$ & $72(36.7)$ & $134(34.6)$ & \\
\hline$\geq 80$ & $94(49.2)$ & $33(16.8)$ & $127(32.8)$ & \\
\hline \multicolumn{5}{|l|}{ Schooling } \\
\hline None & $171(90.5)$ & $21(10.9)$ & $65(17.3)$ & $<0,001$ \\
\hline Some & $18(9.5)$ & $172(89.1)$ & $311(82.7)$ & \\
\hline \multicolumn{5}{|l|}{ Marital status* } \\
\hline Without partner & $119(62.3)$ & $97(49.5)$ & $268(69.6)$ & $<0,001$ \\
\hline With partner & $72(37.7)$ & $99(50.5)$ & $117(30.4)$ & \\
\hline \multicolumn{5}{|l|}{ Children } \\
\hline Yes & $119(62.3)$ & $178(90.8)$ & $297(76.7)$ & $<0,001$ \\
\hline No & $72(37.7)$ & $18(9.2)$ & $90(23.3)$ & \\
\hline \multicolumn{5}{|c|}{ Income* (minimum salary) } \\
\hline Up to 1 & $102(60.7)$ & $98(51.9)$ & $200(56.0)$ & 0,003 \\
\hline 1 to 3 & $52(31.0)$ & $86(45.5)$ & $138(38.7)$ & \\
\hline+3 & $14(8.3)$ & $5(2.6)$ & $19(5.3)$ & \\
\hline
\end{tabular}

* Missing information (interviewees could not respond). 
A total of $2.6 \%$ of the institutionalized elderly persons did not use medication, while among those living at home the proportion was $11.8 \%(\mathrm{p}=0.001)$ (Table 2). The percentage of institutionalized elderly persons that used six or more drugs was 57.4, compared to $22.5 \%(\mathrm{p}<0.001)$ of those who lived at home. There was no significant difference in self-reported health between institutionalized and non-institutionalized elderly.

In terms of estimated risk, crude analysis showed that as age advances, the chance of institutionalization increases. Elderly people who did not have a partner, who were illiterate, who did not have children, who did not practice physical activity, who needed assistance to walk or did not walk, who used medication, who had been diagnosed with Alzheimer's disease, other non-specified dementias, Parkinson's, or stroke motor sequelae had greater chances of institutionalization. The elderly persons who exhibited cognitive impairment (in the MMSE and PFAQ Tests) and were dependent for BADL presented a statistically greater risk of institutionalization (Table 3).

The following variables remained significant after adjusted analysis: without a partner (single, separated, widowed) $(\mathrm{OR}=9.7$ - CI95\%: 4.03-23.46), absence of children $(\mathrm{OR}=4.0$ - CI95\%:1.73-9.28). Cognitive impairment (OR=11.4 - CI95\%: 5.59-23.40) and dependence in BADL (OR=10.9 - CI95\%: 5.2622.72) (Table 3).

Table 2. Distribution of institutionalized elderly (cases) and those living at home (control) for clinical variables (N=387). Passo Fundo, Rio Grande do Sul, 2014.

\begin{tabular}{|c|c|c|c|c|}
\hline Variables & $\begin{array}{l}\text { Cases } \\
\mathrm{n}(\%)\end{array}$ & $\begin{array}{c}\text { Controls } \\
\text { n }(\%)\end{array}$ & $\begin{array}{l}\text { Total } \\
\mathrm{n}(\%)\end{array}$ & $p$ \\
\hline \multicolumn{5}{|c|}{ Performs physical activity } \\
\hline Yes & $58(30.4)$ & $110(56.1)$ & $168(43.4)$ & $<0,001$ \\
\hline No & $133(69.6)$ & $86(43.9)$ & $219(56.6)$ & \\
\hline \multicolumn{5}{|c|}{ Difficulty walking } \\
\hline Yes & $96(50.3)$ & $24(12.2)$ & $120(31.0)$ & $<0,001$ \\
\hline No & $95(49.7)$ & $172(87.8)$ & $267(69.0)$ & \\
\hline \multicolumn{5}{|c|}{ Alzheimer's* } \\
\hline Yes & $50(26.3)$ & $1(0.5)$ & $51(13.2)$ & $<0,001$ \\
\hline No & $140(73.7)$ & $195(99.5)$ & $335(86.8)$ & \\
\hline \multicolumn{5}{|c|}{ Parkinson's* } \\
\hline Yes & $18(9.5)$ & $4(2.0)$ & $22(5.7)$ & 0.002 \\
\hline No & $172(90.5)$ & $192(98.0)$ & $364(94.3)$ & \\
\hline \multicolumn{5}{|c|}{ Other dementias } \\
\hline Yes & $26(13.7)$ & $2(1.0)$ & $28(7.3)$ & $<0.001$ \\
\hline No & $164(86.3)$ & $194(99.0)$ & $358(92.7)$ & \\
\hline \multicolumn{5}{|c|}{ Stroke motor sequelae } \\
\hline Yes & $26(13.7)$ & $5(2.6)$ & $31(8.0)$ & $<0.001$ \\
\hline No & $164(86.3)$ & $191(97.4)$ & $355(92.0)$ & \\
\hline \multicolumn{5}{|c|}{ Arterial hypertension } \\
\hline Yes & $84(44.2)$ & $137(69.9)$ & $221(57.3)$ & $<0.001$ \\
\hline No & $106(55.8)$ & $59(30.1)$ & $165(42.7)$ & \\
\hline \multicolumn{5}{|c|}{ Arterial hypertension } \\
\hline Yes & $26(13.7)$ & $53(27.0)$ & $79(20.5)$ & 0.001 \\
\hline
\end{tabular}


Continued from Table 2

\begin{tabular}{|c|c|c|c|c|}
\hline Variables & $\begin{array}{l}\text { Cases } \\
\mathrm{n}(\%)\end{array}$ & $\begin{array}{c}\text { Controls } \\
\mathrm{n}(\%)\end{array}$ & $\begin{array}{l}\text { Total } \\
\mathrm{n}(\%)\end{array}$ & $p$ \\
\hline No & $164(86.3)$ & $143(73.0)$ & $307(79.5)$ & \\
\hline \multicolumn{5}{|l|}{ Cancer } \\
\hline Yes & $6(3.2)$ & $21(10.7)$ & $27(7.0)$ & 0.004 \\
\hline No & $184(96.8)$ & $175(89.3)$ & $359(93.0)$ & \\
\hline \multicolumn{5}{|l|}{ Medication } \\
\hline Yes & $186(97.4)$ & $172(88.2)$ & $358(92.7)$ & 0.001 \\
\hline No & $5(2.6)$ & $23(11.8)$ & $28(7.3)$ & \\
\hline \multicolumn{5}{|l|}{ Cognitive impairment } \\
\hline Yes & $155(81.2)$ & $25(12.8)$ & $180(46.5)$ & $<0.001$ \\
\hline No & $36(18.8)$ & $171(87.2)$ & 207 (53.5) & \\
\hline \multicolumn{5}{|l|}{ Dependent for BADL } \\
\hline Yes & $145(75.9)$ & $19(9.7)$ & $164(42.4)$ & $<0.001$ \\
\hline No & $46(24.1)$ & $177(90.3)$ & $223(57.6)$ & \\
\hline \multicolumn{5}{|l|}{ Self-reported health } \\
\hline Excellent / good & $94(49.2)$ & $105(53.6)$ & $199(51.4)$ & 0.391 \\
\hline Regular/poor/very poor & $97(50.8)$ & $91(46.4)$ & 188 (48.6) & \\
\hline
\end{tabular}

Table 3. Gross and adjusted analysis of factors associated with the institutionalization of elderly persons. Passo Fundo, Rio Grande do Sul, 2014.

\begin{tabular}{|c|c|c|c|c|}
\hline Variables & OR* (IC95\%) & $p$ & OR十 (IC95\%) & $p$ \\
\hline Gender & & 0.067 & & \\
\hline Male & 1.00 & & & \\
\hline Female & $1.47(0.96-2.25)$ & & & \\
\hline Age (year) & & $<0.001$ & & \\
\hline $60-69$ & 1.00 & & & \\
\hline $70-79$ & $2.23(1.32-3.79)$ & & & \\
\hline$\geq 80$ & $7.40(3.95-13.88)$ & & & \\
\hline Marital status & & $<0.001$ & & $<0.001$ \\
\hline Partner & 1,00 & & 1.00 & \\
\hline Without partner & $9.69(5.17-18.15)$ & & $9.72(4.03-23.46)$ & \\
\hline Schooling & & $<0.001$ & & \\
\hline With schooling & 1.00 & & & \\
\hline Without schooling & $2.59(1.45-4.60)$ & & & \\
\hline Children & & $<0.001$ & & 0.001 \\
\hline Yes & 1.00 & & 1.00 & \\
\hline No & $5.98(2.38-6.70)$ & & $4.01(1.73-9.28)$ & \\
\hline Physical activity & & $<0.001$ & & \\
\hline Yes & 1.00 & & & \\
\hline No & $2.93(1.90-4.52)$ & & & \\
\hline
\end{tabular}


Continued from Table 3

\begin{tabular}{|c|c|c|c|c|}
\hline Variables & OR* (IC95\%) & $p$ & OR十 (IC95\%) & $p$ \\
\hline Independent gait & & $<0.001$ & & \\
\hline Yes & 1.00 & & & \\
\hline No & $7.24(4.12-12.72)$ & & & \\
\hline Medication & & $<0.001$ & & \\
\hline No & 1.00 & & & \\
\hline Yes & $4.97(1.81-13.60)$ & & & \\
\hline Alzheimer's & & $<0.001$ & & \\
\hline No & 1.00 & & & \\
\hline Yes & 69.64 (8.06-601.81) & & & \\
\hline \multicolumn{5}{|l|}{ Other dementias } \\
\hline No & 1.00 & $<0.001$ & & \\
\hline Yes & $15.37(3.42-68.94)$ & & & \\
\hline Parkinson's & & 0.001 & & \\
\hline No & 1.00 & & & \\
\hline Yes & $4.50(1.52-13.29)$ & & & \\
\hline Stroke motor sequelae & & $<0.001$ & & \\
\hline No & 1.00 & & & \\
\hline Yes & $6.05(2.22-16.49)$ & & & \\
\hline Cognitive impairment & & $<0.001$ & & $<0.001$ \\
\hline No & 1.00 & & 1.00 & \\
\hline Yes & $29.45(13.73-63.15)$ & & $11.43(5.59-23.40)$ & \\
\hline BADL Independence & & $<0.001$ & & $<0.001$ \\
\hline Yes & 1.00 & & 1.00 & \\
\hline No & $29.36(13.46-64.01)$ & & $10.94(5.26-22.72)$ & \\
\hline
\end{tabular}

*OR: Gross Odds Ratio; †OR: Adjusted Odds Ratio calculated by multiple logistic; BADL: Basic activity of daily living. a.

\section{DISCUSSION}

When the groups of institutionalized and noninstitutionalized elderly persons were compared, a higher concentration of elderly individuals aged over 80 years was observed in the care facilities, a finding that corroborates those in literature ${ }^{12,13}$. One survey reported that the risk of institutionalization is 9.5 times greater among elderly persons aged over 80 years ${ }^{12}$. However, the analyzes of the present study allowed us to conclude that advanced age is not associated with institutionalization, but rather with the dependencies that accompany it. Factors that may explain this finding are that, with increasing age, situations of dependence increase, whether due to physical or mental decline, frailties, or a greater chance of presenting chronic noncommunicable diseases and their complications, which often motivates the process of institutionalization ${ }^{14}$.

In terms of marital situation, the institutionalized group had a high proportion of elderly people without a partner (90.5\%), a common finding in surveys carried out in institutions $\mathrm{s}^{15-17}$. The absence of children was also relevant in the process of institutionalization. In such situations, when the elderly confront difficulties in daily living or have other dependencies, they also face difficulties in receiving care at home due to changes in family profile (absence of children or children 
who emigrated). The decision to remain single, the absence, whether by widowhood, separation or divorce, of a spouse, who are traditionally shown to be the main caregivers at home, increases the risk of institutionalization ${ }^{17}$. There are reports in literature that people living alone have a greater chance of institutionalization, with men having a $70 \%$ greater chance, and women a 30\% greater chance. Those with spouses are protected from institutionalization by the fact that, on average, they have a higher education and income, their own home and better housing conditions ${ }^{18}$.

The proportion of physical inactivity identified in the institutionalized elderly was in agreement with other studies ${ }^{13,15}$. However, the physical activity variable lost significance when the walking related variable was entered in the multiple model. This is because, for the performance of most physical activities, it is necessary for the individual to be able to walk, with proper functioning of the cardiovascular, respiratory, neuromotor and metabolic systems, among others ${ }^{19}$.

The main diseases and complications initially associated with institutionalization in the gross analysis were Alzheimer's disease, Parkinson's disease, other unspecified dementias and stroke motor sequelae, or in other words, cognitive and functional impairments. However, in multiple analysis, these variables lost their significance when BADL dependence and cognitive impairment entered the model. This is because the sequelae of a stroke can interfere strongly with performing the basic activities of daily life ${ }^{20}$, which can be extended to diseases that damage neuromuscular function, such as Parkinson's and the advanced stages of Alzheimer's.

Joint wear and loss of muscle strength often occur during the aging process, and can impede stable mobility. Diseases of the central nervous system and musculoskeletal and cardiovascular diseases also make walking difficult ${ }^{21}$. Therefore, difficulty in walking due to chronic diseases and complications reduces the practice of physical activity and directly interferes in the performance of BADL. It is worth emphasizing that physical activity can promote benefits at any age, leading to improvements in quality of life and the maintenance of functional capacity and preserving the physical and mental abilities acquired throughout life ${ }^{22}$; Thus, the practice of physical activity reduces the installation of several factors related to institutionalization, mainly dependence in BADL.

The identification of cognitive impairment was associated with institutionalization. In a comparative study of cognitive impairment and functional capacity with institutionalized and non-institutionalized elderly people, MMSE performance was lower and there was greater impairment of functional capacity in the institutionalized group ${ }^{23}$.

Diagnosed dementia affects between 2 and $8 \%$ of the population over 60 years of age $\mathrm{a}^{24}$, which is close to the proportion found in the community in the present study $(1.5 \%$ of individuals had dementia recorded in their medical records). However, the results in institutions are substantially higher. One of the reasons that explains the higher percentage of dementias diagnosed in LTCFE is advanced age, as after 65 years of age the proportion doubles with each five year incremement ${ }^{24}$. Moreover, the factor of dementia is strongly associated with institutionalization ${ }^{25,26}$ as the proportion of this disease tends to be higher in such settings.

In a longitudinal study in Hong Kong ${ }^{27}$, it was observed that of the 749 individuals aged $\geq 65$ years, 80 were institutionalized, and that cognitive impairment was indicative of institutionalization, which corroborates the findings of this study. The occurrence of institutionalization practically triples when associated with functional disability ${ }^{27}$.

The reasons that lead those responsible for elderly persons to institutionalize such individuals are related to the worsening of health conditions. A study conducted at the University of Indiana ${ }^{28}$, USA, indicated that elderly persons with Alzheimer's are more prone to institutionalization, as home care is more complex and exhausting because of dependencies and the need for continued attention. An American cohort study ${ }^{29}$, which used the same instrument as this study (MMSE), reported that lower scores are associated with institutionalization in all the periods investigated, including a risk of institutionalization at the beginning of symptoms of cognitive impairment. 
As for dependence in BADL, the institutionalized group displayed significantly higher proportions than the group of elderly persons residing at home. The percentage of $75.9 \%$ is close to that found in other studies ${ }^{12,14,30}$. Some factors contribute to dependence, such as the advanced ages found in LTCFE, which is accompanied by motor deficit, muscle weakness, cognitive impairment and the presence of chronic non-communicable diseases ${ }^{30}$. In a Brazilian crosssectional study $y^{31}$ performed in LTCFE of the southeast and center-west regions, it was found that functional dependence is associated with chronic diseases (hypertension, diabetes, joint problems), walking difficulties and cognitive impairment. The authors identified that, among the institutionalized elderly with BADL dependency, $82.2 \%$ had severe mobility loss. Furthermore, $86.5 \%$ of those dependent for BADL had a low MMSE score.

As in the findings of the present study, other studies have demonstrated the association between BADL dependence and cognitive impairment in institutions $s^{23,31,32}$. Another study ${ }^{33}$ states that, both in the community and in LTCFE, cognitive impairment demonstrates a direct association with dependencies in daily activities. Elderly persons with cognitive impairment, therefore, have a greater dependency in BADL and, consequently, are more likely to be institutionalized ${ }^{34}$.

\section{REFERENCES}

1. Floriano LA, Azevedo RCS, Reiners AAO, Sudré MRS. Cuidado realizado pelo cuidador familiar ao idoso dependente, em domicílio, no contexto da Estratégia de Saúde da Família. Texto Contexto Enferm. 2012;21(3):543-8.

2. Michel T, Lenardt MH, Betiolli SE, Neu DKM. Significado atribuído pelos idosos à vivência em uma instituição de longa permanência: contribuições para o cuidado de enfermagem. Texto Contexto Enferm. 2012;21(3):495-504.

3. Camarano AA, organizadora. Cuidados de longa duração para a população idosa: um novo risco social a ser assumido? Rio de Janeiro: IPEA; 2010. Conclusão. p. 337-49.

4. Küchemann BA. Envelhecimento populacional, cuidado e cidadania: velhos dilemas e novos desafios. Soc Estado. 2012;1(27):165-80.
Moreover, the results of a Brazilian study on the factors associated with institutionalization ${ }^{12}$ showed that the variables gender, age, marital status, schooling, functional disability and physical activity were associated with referral to LTCFE. The present study differed in its findings for gender, age, schooling and physical activity but agreed in finding an association with marital situation and functional incapacity, and added the risk factor of not having children. This study also adds to the investigation of cognitive impairment, which has become an important factor in predisposing individuals to institutionalization.

Among the limitations of the study, it is believed that the possibility of the underreporting of chronic diseases, especially among elderly persons living in households, was ameliorated by the consultation of the records of the Basic Health Unit and the patient's medical records in the LTCFE.

\section{CONCLUSION}

The present study found that the factors that predispose the elderly to institutionalization were the absence of a spouse, not having children, exhibiting cognitive impairment and dependence for basic activities of daily living.

5. Perlini NMO, Leite MT, Furini AC. Em busca de uma instituição para a pessoa idosa morar: motivos apontados por familiares. Rev Esc Enferm USP. 2007;41(2):229-36.

6. Fonseca ACC, Scoralick F, Silva CL, Bertolino A, Palma D, Piazzolla L. Perfil epidemiológico de idosos e fatores determinantes para a admissão em instituições de longa permanência do Distrito Federal. Brasília Méd. 2011;48(4):366-71.

7. Instituto Brasileiro de Geografia e Estatística. Censo Demográfico 2010 [Internet]. Rio de Janeiro: IBGE; 2010 [acesso 14 out. 2014]. Disponível em: http://www.sidra.ibge.gov.br/bda/tabela/protabl. asp?c $=1378 \& \mathrm{z}=\mathrm{t} \& \mathrm{o}=25 \& \mathrm{i}=\mathrm{P}$

8. Bertolucci PHF, Brucki SMD, Campacci SR, Juliano Y. O mini-exame do estado mental em uma população geral: impacto da escolaridade. Arq. Neuropsiquiatr. 1994;52(1):1-7. 
9. Pfeffer RI, Kurosaki TT, Harrah Jr CH, Chance JM, Filos S. Measurement of functional activities in older adults in the community. J Gerontology. 1982;37(3):323-9.

10. Brasil. Ministério da Saúde, Secretaria de Atenção à Saúde, Departamento de Atenção Básica. Envelhecimento e saúde da pessoa idosa. Brasília, DF: MS; 2006.

11. Katz S, Ford AB, Moskowitz RW, Jackson BA, Jaffe MW. Studies of illness in the aged. The index of ADL: a standardized measure of biological and psychosocial function. JAMA. 1963;185(12):914-9.

12. Del Duca GF, Silva SG, Thumé E, Santos IS, Hallal PC. Indicadores da institucionalização de idosos: estudo de casos e controles. Rev Saúde Pública. 2012;46(1):147-53.

13. Menezes RL, Bachion MM, Souza JT, Nakatani AYK. Estudo longitudinal dos aspectos multidimensionais da saúde de idosos institucionalizados. Rev Bras Geriatr Gerontol. 2011;14(3):485-96.

14. Sousa KT, Mesquita LAS, Pereira LA, Azeredo CM. Baixo peso e dependência funcional em idosos institucionalizados de Uberlândia (MG), Brasil. Ciênc Saúde Coletiva. 2014;19(8):3513-20.

15. Oliveira MPF, Novaes MRCG. Perfil socioeconômico, epidemiológico e farmacoterapêutico de idosos institucionalizados de Brasília, Brasil. Ciênc Saúde Coletiva. 2013;18(4):1069-78.

16. Alencar MA, Bruck NNS, Pereira BC, Câmara TMM, Almeida RDS. Perfil dos idosos residentes em uma instituição de longa permanência. Rev Bras Geriatr Gerontol. 2012;15(4):785-96.

17. Lisboa CR, Chianca TCM. Perfil epidemiológico, clínico e de independência funcional de uma população idosa institucionalizada. Rev Bras Enferm. 2012;65(3):482-7.

18. Nihtilä E, Martikainen P. Why older people living with a spouse are less likely to be institutionalized: the role of socioeconomic factors and health characteristics. Scand. J. Public Health. 2008;36(1):35-43.

19. Conselho Federal De Educação Física. Nota técnica CONFEF n 002/2012 [Internet]. Rio de Janeiro: CONFEF; 2012 [acesso 11 out. 2014]. Disponível em: http://www.confef.org.br/extra/conteudo/default. asp?id $=837$
20. Dantas CMHL, Bello FA, Barreto KL, Lima LS. Capacidade funcional de idosos com doenças crônicas residentes em instituições de longa permanência. Rev Bras Enferm. 2013;66(6):914-20.

21. Paixão Júnior CM, Heckman MF. Distúrbios da postura, marcha e quedas. In: Freitas EV, Py L. Tratado de Geriatria e Gerontologia. 3. ed. São Paulo: Guanabara Koogan; 2011. p.1062-74.

22. Mazini Filho ML, Zanella AL, Aidar FJ, Silva AMS, Salgueiro RS, Matos DG. Atividade física e envelhecimento humano: a busca pelo envelhecimento saudável. Rev Brasi Ciênc Envelhec Hum. 2010;7(1):97-106.

23. Trindade APNT, Barboza MA, Oliveira FB, Borges APO. Repercussão do declínio cognitivo na capacidade funcional em idosos institucionalizados e não institucionalizados. Fisioter Mov. 2013;26(2):281-9.

24. World Health Organization. Media Centre. Fact Sheets: Dementia [Internet]. Genebra: WHO; 2012. [acesso 14 nov. 2014]. Disponível em: www.who.int/ mediacentre/factsheets/fs362/en/

25. Gnjidic D, Stanaway FF, Cumming R, Waite L, Blyth F, Naganathan V, et al. Mild cognitive impairment predicts institutionalization among older men: a population-based cohort study. PLoS One. 2012;7(9):1-8.

26. Mello BLD, Haddad MCL, Dellaroza MSG. Avaliação cognitive de idosos institucionalizados. Acta Sci Health Sci. 2012;34(1):95-102.

27. Chau PH, Woo J, Kwok T, Chan F, Hui E, Chan KC. Usage of community services and domestic helpers predicted institutionalization of elders having functional or cognitive impairments: a 12-month longitudinal study in Hong Kong. J Am Med Dir Assoc. 2012;13(2):169-75.

28. Mclennon SM, Habermann B, Davis LL. Deciding to institutionalize: why do family members cease caregiving at home? J Neurosci Nurs. 2010;42(2):95-103.

29. Cohen-mansfield J, Wirtz PW. Predictors of entry to the nursing home: Does length of follow-up metter? Arch Gerontol Geriatr. 2011;53(3):309-15.

30. Smanioto FN, Haddad MCFL. Índice de Katz aplicado a idosos institucionalizados. Rev Rene 2011;12(1):18-23. 
31. Mattos IE, Carmo CN, Santiago LM, Luz LL. Factors associated with functional incapacity in elders living in long stay institutions in Brazil: a crosssectional study. BMC Geriatr. 2014;14(47):1-9.

32. Oliveira PH, Mattos IE. Prevalência e fatores associados à incapacidade funcional em idosos institucionalizados no município de Cuiabá, Estado de Mato Grosso, Brasil, 2009-2010. Epidemiol Serv Saúde. 2012;21(3):395-406.

Received: March 6, 2016

Reviewed: October 3, 2016

Accepted: October 31, 2016
33. Yoshida D, Ninomiya T, Doi Y, Hata J, Fukuhara M, Ikeda F, et al. Prevalence and causes of functional disability in an elderly general population of japanese: The Hisayama Study. J Epidemiol. 2012;22(3):222-9.

34. Nogueira D, Reis E, Atalaia R, Raposo P, Serrasqueiro R. Ageing, disability and long-term care. BMC Health Serv Res. 2011;11(supl 1):1-2. 


\section{ERRATA}

No artigo "Factors associated with the institutionalization of the elderly: a case-control study"', publicado em Revista Brasileira de Geriatria e Gerontologia, v. 19, n. 6, p. 1004-1014, 2016, DOI: http://dx.doi. org/10.1590/1981-22562016019.160043, na página 1004, o nome da segunda autora está errado.

Onde se lê:

Marilene Rodrigues ${ }^{1}$

Leia-se:

Marilene Rodrigues Portella ${ }^{1}$ 